\title{
Secular trends in growth of African Pygmies and Bantu
}

\author{
Paola Travaglino, ${ }^{1}$ Cristina Meazza, ${ }^{1}$ Sara Pagani, ${ }^{1}$ Giada Biddeci, ${ }^{1}$ Mauro Bozzola ${ }^{1}$ \\ ${ }^{1}$ Paediatrics Department, University of Pavia, Foundation IRCCS Policlinico San Matteo, Pavia, Italy
}

\begin{abstract}
OBJECTIVE: The aim of this study was to investigate whether a secular trend in growth occurred during the last century in Pygmies from Cameroon (West Pygmies) and in Bantu rural farmers, the latter being studied to serve as controls.-DESIGN: The evolution in height of West Pygmies and Bantu farmers from 1911 to 2006 was evaluated using data from the literature as well as data gathered by our research team during an expedition to Cameroon in 2006. RESULTS: During the last century, no secular trend in west Pygmies is apparent, as height changed from $151 \mathrm{~cm}$ to $155 \mathrm{~cm}$ in males and from $143 \mathrm{~cm}$ to $146 \mathrm{~cm}$ in females. A small though significant $(p=0.026)$, increment (about $2 \mathrm{~cm}$ ) was observed only in female subjects during the last ten years. By contrast, Bantu heights show a significant change from 1943 to 2006 for both males (from $159 \mathrm{~cm}$ to $172 \mathrm{~cm} ; p=0.025$ ) and females (from $148 \mathrm{~cm}$ to $160 \mathrm{~cm} ; p=0.029$ ). CONCLUSIONS: Over the last century, the Bantu population exhibited a significant secular trend for height, whereas West Pygmies did not increase their linear growth. The lack of secular trend in Pygmies possibly suggests that their stature reflects adaptation to the forest lifestyle. We may hypothesize that not only environmental but epigenetic factors have also contributed to their growth potential.
\end{abstract}

Key words: African Bantu, African Pygmies, Height, Secular trend

\section{INTRODUCTION}

Human height is determined by various factors such as genetic predisposition, hormones as well as environmental factors, such as nutrition. Meanwhile, it is well established that secular growth trends depend upon environmental and socio-economic factors. ${ }^{1}$ Population height has been recognized as

\section{Address for correspondence:}

Prof. Mauro Bozzola, M.D., Dipartimento di Scienze Pediatriche, Università degli Studi di Pavia, Fondazione IRCCS San Matteo, Piazzale C. Golgi 2, 27100 Pavia, Italy, Tel.: +390382502891, Fax: +390382527976,

E-mail: mauro.bozzola@unipv.it

Received 30-06-10, Revised 17-12-10, Accepted 10-01-11 an index of welfare, while historical height records have been used to describe improvements in living standard. ${ }^{2}$ In developed countries, improvements in socio-economic conditions and lifestyle have led to positive growth trends in the $20^{\text {th }}$ century, ${ }^{3}$ while in recent years physical development has reached a plateau, suggesting that full genetic potential has been achieved and/or that socio-economic conditions have ceased to improve. ${ }^{4}$ Furthermore, recent studies also suggest that the magnitude of the secular trend toward an earlier age of menarche is slackening in industrialized countries. ${ }^{5}$ In contrast, secular trends seem to be in their early stages in some developing countries in which nutritional status and public health standards are still evolving. ${ }^{6}$ 
Traditionally, short stature has been defined as a height below the 2 standard deviation for age when compared with sex-specific standards. Short stature is generally not associated with hormonal defects and such cases are mainly designated as idiopathic, which identifies short subjects in whom the cause has not been detected. The Pygmies are one of the shortest populations worldwide with normal body proportions, although variability among ethnic groups exists, as evidenced by the finding that Pygmies living in the Ituri forest of the Democratic Republic of Congo are on average $8 \mathrm{~cm}$ shorter than West Pygmies living in the Central African Republic or the Baka Pygmies of Eastern Cameroon. ${ }^{7}$ The physiological basis for their extremely short stature is still a subject of speculation as well as of investigation since it may significantly contribute to our knowledge of human growth processes. Most studies have concluded that the Pygmy growth pattern is normal up to the time of puberty and that their short stature is primarily due to insufficient growth acceleration at puberty. ${ }^{8}$ On the other hand, Bailey has suggested that impaired growth in Pygmies occurs from birth onward, since in a longitudinal study it was shown that Pygmy children were also shorter than their neighbouring Bantu controls even at birth. ${ }^{9}$

The aim of the present study was to determine whether or not a secular trend in height has occurred in West Pygmies and their Bantu neighbours during the period 1911-2006, using data from the literature as well as our own gathered during an expedition to South-East Cameroon in 2006.

\section{SUBJECTS AND METHODS}

Data on the adult height of West Pygmies and the Bantu (Table 1) of Cameroon were obtained from previous studies conducted from 1911 to 1996. The first study on the stature of West Pygmies living in Cameroon was carried out in 1911 by Poutrin. ${ }^{10}$ From 1938 and up to the end of the $20^{\text {th }}$ century, there has been a significant number of studies on the growth of West Pygmies (Table 1). The first study on African Bantu height was carried out in $1943^{11}$ followed by three others conducted in $1969,{ }^{13} 1993^{14}$ and 2009 (Table 1).

The most recent data ${ }^{12}$ on the adult height of these populations were gathered during an expedi-
Table 1. Height studies of West Pygmies and Bantu (1911 to 2009)

\begin{tabular}{|c|c|c|c|}
\hline & Study & Males N & Females N \\
\hline \multirow{12}{*}{ 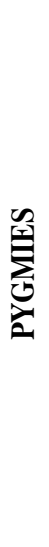 } & Poutrin $1911^{10}$ & 51 & 16 \\
\hline & Pales $1938^{28}$ & 33 & 19 \\
\hline & Vallois, $1940^{29}$ & 13 & 10 \\
\hline & Lalouel, $1950^{30}$ & 53 & 43 \\
\hline & Cresta $1965^{31}$ & 87 & 56 \\
\hline & Pennetti et al $1967^{32}$ & 427 & 392 \\
\hline & Froment et al $1968^{33}$ & 107 & 124 \\
\hline & Cavalli-Sforza $1969^{13}$ & 48 & 43 \\
\hline & Merimee et al $1987^{8}$ & 48 & 43 \\
\hline & Koppert et al $1993^{14}$ & 107 & 124 \\
\hline & Dulloo et al $1996^{7}$ & 40 & 27 \\
\hline & Bozzola et al $2009^{12}$ & 33 & 48 \\
\hline \multirow{4}{*}{ 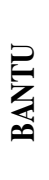 } & Gusinde $1943^{11}$ & 35 & 39 \\
\hline & Cavalli-Sforza $1969^{13}$ & 50 & 62 \\
\hline & Koppert et al $1993^{14}$ & 243 & 329 \\
\hline & Bozzola et al $2009^{12}$ & 31 & 48 \\
\hline
\end{tabular}

tion to South-East Cameroon led by our research team in 2006. The expedition group reached West Pygmy villages near the boundaries of the Gabon and Congo and the Central African Republic, the Dja Reserve, at the edge of the forest near rural Bantu farmers. Little is known about this group of Pygmies. Very incomplete censuses are available and the local interpreter told us that Pygmies from the villages, with negligible contacts with other nonPygmy populations, number a few hundred. Body weight and height were measured in a group of 81 Baka Pygmy subjects (33 males, aged $40 \pm 14$ years; 48 females, aged $24 \pm 11$ years) and in 79 Bantu (31 males, aged $30 \pm 10$ years; 48 females, aged $24 \pm 8$ years). The Bantu subjects were evaluated as controls. It was decided to consider as adults those subjects older than 18 to ensure that they have reached final height, some previous studies showing that Pygmy children enter puberty at about twelve years. ${ }^{8}$ The age of illiterate adults was obtained with the help of the camp chiefs and interpreters roughly calculated, in relation to important events and agricultural or gathering activities of the villagers. No information regarding births for any subject was available. Body weight was measured using electronic scales and height was determined to the nearest $0.5 \mathrm{~cm}$ against a vertical wall perpendicular to a surface on which the subject stood barefoot. Verbal consent from the camp chiefs and from all subjects was obtained prior 
to clinical examination and anthropometric measurement, in accordance with the local ethics committee.

Statistical analysis was performed using MedCalc statistical software (MedCalc, Mariakerke, Belgium). Data were expressed as mean \pm standard deviation and were normally distributed according to the Kolmogorov-Smirnov test. Means of height were compared by the $\mathrm{t}$-test for comparison of means and regression lines were analyzed. A p value less than 0.05 was considered to be statistically significant.

\section{RESULTS}

During our expedition to Cameroon in 2006, no signs of malnutrition were observed based on standard clinical examination and the body mass index (BMI) values, the latter being in the normal range in both Pygmies (males:20.8 $\pm 2.0 \mathrm{~kg} / \mathrm{m}^{2}$; females $20.9 \pm 2.0$ $\mathrm{kg} / \mathrm{m}^{2}$ ) and Bantu (males: $23.8 \pm 2.6 \mathrm{~kg} / \mathrm{m}^{2}$; females $22.9 \pm 3.5 \mathrm{~kg} / \mathrm{m}^{2}$ ). However, the BMI values of males and females in Bantu were significantly higher compared to those in Pygmies (males: $\mathrm{p}<0.0001$; females $\mathrm{p}=0.016$ ).

The mean heights from the studies in the literature and those of our expedition to Cameroon for West Pygmy and Bantu males and females are shown in Figure 1. No secular trend was observed in West Pygmies over the last century, as height increased from $151 \mathrm{~cm}$ to $155 \mathrm{~cm}$ (median $152.5 \mathrm{~cm}$ ) in males $(\mathrm{p}=0.320)$ and from $143 \mathrm{~cm}$ to $146 \mathrm{~cm}$ (median 145.0 $\mathrm{cm})$ in females $(\mathrm{p}=0.443)$. A small but significant $(p=0.026)$ increment (about $2 \mathrm{~cm})$ was observed only in female subjects during the last ten years. By contrast, the studies on Bantu heights show a secular growth trend from 1943 to 2006 for both males and females. Male Bantu heights increased by about $13 \mathrm{~cm}$ (from $159 \mathrm{~cm}$ to $172 \mathrm{~cm})($ median $163.0 \mathrm{~cm} ; \mathrm{p}=0.025)$ and female heights by about $12 \mathrm{~cm}$ from $148 \mathrm{~cm}$ to 160 $\mathrm{cm}$ (median $154.5 \mathrm{~cm} ; \mathrm{p}=0.029)$.

\section{DISCUSSION}

The present data demonstrate that during the last century no increases in linear growth of West Pygmies (both males and females) occurred, whereas a significant increase in the height of their Bantu neighbours was evident. During the same period, the genetic potential for growth was reached in Europe. In fact, in northern European countries, males attained a mean level of $179-180 \mathrm{~cm}$, and in Italy mean height has increased up to $174 \mathrm{~cm} .^{15}$

It has been accepted that adult height represents the final outcome of a continuous interaction between genetic and environmental factors. ${ }^{16}$ According to Tanner, growth is a mirror of the social conditions prevailing in a given society. ${ }^{17}$ The secular trend in body size and tempo of growth are considered
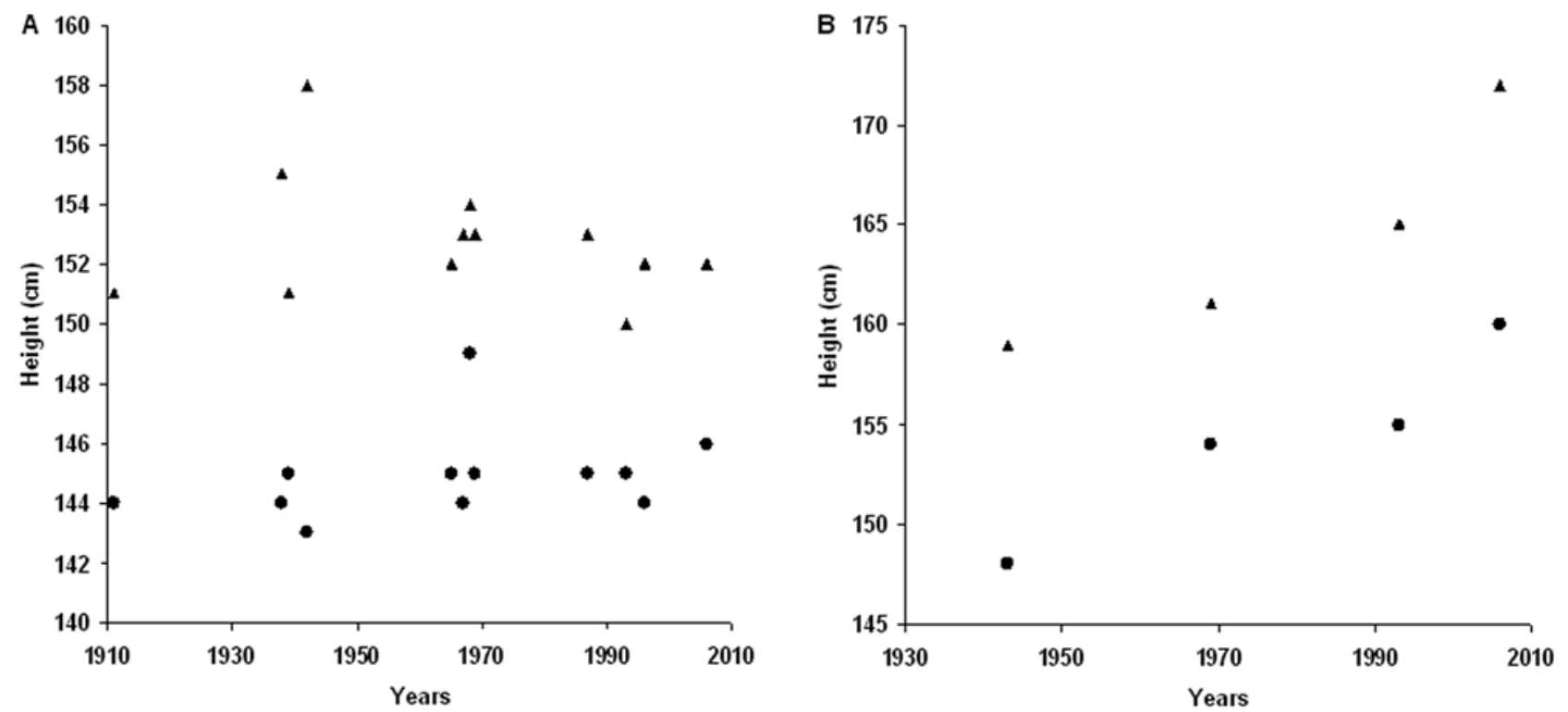

Figure 1. Panel A: mean adult height $(\mathrm{cm})$ of West Pygmy males (triangles) and West Pygmy females (circle) in the $20^{\text {th }}$ century; panel B: mean adult height $(\mathrm{cm})$ of Bantu males (triangles) and Bantu females (circles) in the $20^{\text {th }}$ century. 
reliable markers of health and nutrition among a population and their variation reflects changes in the socio-economic status of the population. Secular variation in height has been observed in almost all industrialized countries during the last century. However, the magnitude of change in growth is not the same in the different subgroups of a population with different socio-demographic backgrounds. ${ }^{18}$ The evidence is that in a given population, positive changes in height may cease if there is no further improvement in the environmental conditions and/ or if the population reaches its genetic growth potential. ${ }^{19}$ Furthermore, growth is mainly achieved during childhood, the traditionally higher growth rate during adolescence having diminished in populations in which the secular increase in tempo of growth has slowed down or stopped. ${ }^{20}$

Data on secular changes in African populations are quite scarce and mainly concern Southern Africans during the first fifty years of the last century. These data have shown a lack or sometimes negative secular trend for adult mean stature, probably reflecting poor nutrition and poverty. ${ }^{21}$

Since increases in height mainly take place during the first two years of life, ${ }^{22}$ the lack of a positive height trend in Pygmy adult subjects may in part be due to the high rate of infectious diseases in infancy. Furthermore, Pygmy BMI values being at the lower limit of normality indicate that Pygmies are in worse nutritional condition than Bantu. In fact, although they usually live on the edge of the forest near Bantu farmers, they have negligible contact with this group and continue to maintain their traditional lifestyle. For example, they still maintain a semi-nomadic lifestyle and frequently live for months in the deep forest gathering and hunting, thus being at increased risk for environmental infections. ${ }^{23-24}$ In the early 1970 s, mud-houses were constructed as part of a government strategy to sedentarize the population and to phase out their nomadic lifestyle. During the last 20 years, the Cameroon Government has attempted to make a census of the Pygmy population by forcing them to live outside the forest, near the Bantu villages and paths. Moreover, a health program was initiated, encouraging them to substitute their traditional remedies with western drugs and striving to improve their sanitation conditions. ${ }^{25}$ Although the Pygmies are reluctant to accept these changes, in the last decade a slow (about $2 \mathrm{~cm}$ ) small increment in adult height was observed in female subjects. These data might indicate that a secular trend is starting now, parallel to the small upgrading in living conditions. In contrast, the Bantu increase in adult height during the last fifty years most likely reflects improvements in hygienic conditions and better nutrition. Another recent study demonstrated a significant increase from 1962 to 2001 in the skeletal maturity and stature of black South African children, indicative of removal of growth constraints due to better social conditions. ${ }^{26}$

Another possibility that may account for the difference between West Pygmies and Bantu subjects is that Pygmies have attained their genetic growth potential and, therefore, their final height will not increase despite improvements in their socio-economic and health conditions. The exact mechanisms and factors involved in the short stature of Pygmies are not yet fully elucidated and are highly likely not to be dependent on their lifestyle. Alternatively, as suggested by Diamond, ${ }^{27}$ it is quite possible that their short stature is epigenetically determined to facilitate adaptation to life in the dense tropical forest and endurance against starvation. Furthermore, their small body size could favour their life in the hot, humid climate of a tropical forest by minimizing the body's heat production during exercise. With regard to possible pathophysiological mechanisms, it must be mentioned that Merimee et $\mathrm{al}^{8}$ reported normal GH secretion but low IGF-I levels. We also recently reported that reduced IGF-I and GHBP levels in Pygmies are associated with a marked decrease of the GHR gene expression which is not associated with variants in the sequence of the GHR gene. This supports the hypothesis of a genetically determined short stature in Pygmies. ${ }^{12}$

Finally, one should also consider that the sample size may not be adequate to unambiguously reveal a secular trend in Pygmies. This is primarily due to the many difficulties involved in reaching and enrolling these subjects.

In conclusion, over the last century the Bantu population from Cameroon exhibited a positive trend for height, while West Pygmies have not increased their linear growth, suggesting either that their short stature is mainly genetically determined, that epigenetic factors are involved and/or that in the regulation of their growth their living conditions have not 
substantially been altered. The results of the present study could be important in that they augment our knowledge concerning Pygmy somatic growth.

\section{ACKNOWLEDGEMENTS}

The authors are grateful to Laurene Kelly for the English revision of the paper.

\section{REFERENCES}

1. Cole TJ, 2003 The secular trend in human physical growth: a biological view. Econ Hum Biol 1: 161-168

2. Steckel R, 1995 Stature and quality of living. J Econ Lit 33: 1903-1940.

3. Fredriks AM, van Buuren S, Burgmeijer RJ, et al, 2000 Continuing positive secular growth change in the Netherlands 1955-1997. Ped Res 47: 316-323.

4. Krawczynski M, Walkowiak J, Krzyzaniak, 2003 Secular changes in body height and weight in children and adolescents in Poznan, Poland, between 1880 and 2000. Acta Paediatr 92: 277-282.

5. Parent S, Teilmann G, Juul A, et al, 2003 The timing of normal puberty and the age limits of sexual precocity: Variations around the world, secular trends, and changes after migration. Endocr Rev 24: 668-693.

6. Castilho LV, Lahr MM, 2001 Secular trends in growth among urban Brazilian children of European descent. Ann Hum Biol 28: 564-574.

7. Dulloo AG, Shahkhalili Y, Atchou G, et al, 1996 Dissociation of systemic GH-IGF-I axis from a genetic basis for short stature in African Pygmies. Eur J Clin Nutr 50: 371-380.

8. Merimee TJ, Zapf J, Hewlett B, et al, 1987 Insulin-like growth factors in pygmies. The role of puberty in determining final stature. New Engl J Med 316: 906-911.

9. Bailey RC, 1991 The comparative growth of Efe pygmies and African farmers from birth to age 5 years. Ann Hum Biol 18: 113-120.

10. Poutrin R, 1911 Contribution à l'étude des Pygmées d'Afrique. Les negrilles du Centre africain. L'Anthropologie 22: 421-549.

11. Gusinde M 1948 Urwaldmenschen am Ituri. Vienna: Springer-Verlag.

12. Bozzola M, Travaglino P, Marziliano N, et al, 2009 The shortness of Pygmies is associated with severe underexpression of the growth hormone receptor. Mol Gen Metab 98: 310-313.

13. Cavalli Sforza LL, 1969 African Pygmies, Academic Press, Orlando.

14. Koppert GJA, Dounias E, Froment A, Pasquet P, et al, 1993 Food consumption in the forest populations of southern coastal Cameroon. In: Hladik CM et al (eds) Tropical forests, people and food. Biocultural Interactions and applications to development. Man and the biosphere series, 13. Paris: UNESCO et Carnforth: The Parthenon Publishing Group, pp, 357-364.
15. Larnkjaer A, Attrup S, Schmidt IM, et al, 2006 Secular change in adult stature has come to a halt in northern Europe and Italy. Acta Paediatr 95: 754-745.

16. Tanner JM, 1992 Growth as a measure of the nutritional and hygienic status of a population. Horm Res 38: 106-115.

17. Tanner JM 1998 A brief history of the study of human growth. In: Ulijaszek SJ, Johnston FE, Preece MA (eds), The Cambridge Encyclopedia of Human Growth and Development, University Press, Cambridge; pp, 2-7.

18. Chinn S, Rona RJ, Price CE, 1989 The secular trend in height of primary school children in England and Scotland 1972-79 and 1979-86. Ann Hum Biol 16: 387-395.

19. Papadimitriou A, Chiotis D, Tsiftis G, et al, 2002 Secular growth changes in the Hellenic population in the twentieth century. Hormones (Athens) 1: 245-250.

20. Brundtland GH, Liestol K, Walloe L, 1980 Height, weight and menarcheal age of Oslo schoolchildren during the last 60 years. Ann Hum Biol 7: 307-322.

21. Tobias PV, 1990 Adult stature in southern African Negroes-further evidence on the absence of a positive secular trend. S Afr Med J 78: 97-101.

22. Cole TJ, 2000 Secular trends in growth. Proc Nutr Soc 59: 317-324.

23. Sureau P, Jaeger G, Pinerd G, et al, 1977 Sero-epidemiological survey of arbovirus diseases in the Bi-Aka pygmies of Lobaye, Central African Republic. Bull Soc Pathol Exot Filiales 70: 131-137.

24. Mazzuccato A, 2002, I Pigmei. Storia del più antico popolo della foresta. Available from:http://www.gfbv. it/3dossier/africa/pigmei.html

25. INDISCO. Available from:http://www.ilo.org/public/ french/region/afpro/yaounde/download/ouagadougou/ indigpeopcamer.pdf

26. Hawley NL, Rousham EK, Norris SA, et al, 2009 Secular trends in skeletal maturity in South Africa: 1962-2001. Ann Hum Biol 36: 584-594.

27. Diamond JM, 1991 Why are pygmies small? Nature 354: 111-112.

28. Pales W, 1938 Contribution à l'étude anthropologique des West. L'Anthropologie 48: 503-520.

29. Vallois HV, 1940 New research on the western negrillos. Am J Phys Anthrop 26: 449-471.

30. Lalouel J, 1950 Les West des Bas Oubangui. Bull. Méd. Soc. Anthrop X: 60-98.

31. Cresta M, 1965 Contributo alla conoscenza antropologica dei West. Ricerca Scientifica 4: 109-129.

32. Pennetti V, Sgaramella-Zonta L, Astolfi P, 1986 General health of the African Pygmies of the Central African Republic. In: Cavalli Sforza, LL (ed) African Pygmies, Academic Press, Orlando; pp, 127-138.

33. Froment A, Koppert GJA, Loung J-F 1993 "Eat well, live well": nutritional status and health of forest populations in southern Cameroon. In: Hladik CM et al (eds), Tropical forests, people and food. Biocultural Interactions and applications to development. Man and the biosphere series, 13. Paris: UNESCO et Carnforth: The Parthenon Publishing Group; pp, 357-364. 